Kurudayıoğlu, M. ve Soysal, T. (2018). Illkokul Türkçe 1 ders kitabının öğretim programındaki temel beceriler açısından incelenmesi. Ana Dili Ĕgitimi Dergisi, 6(3), 670-683.

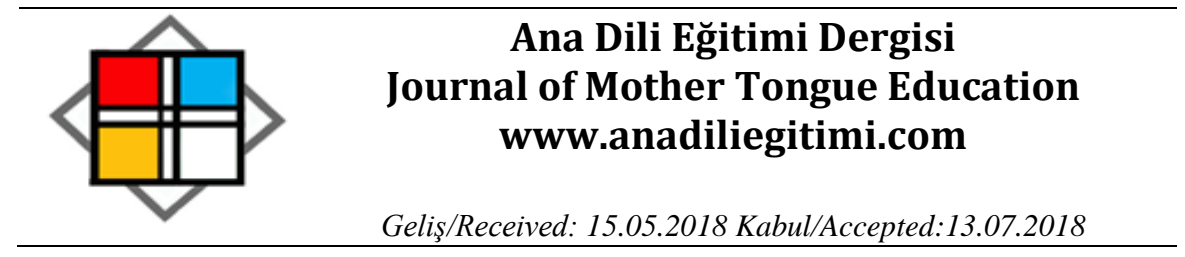

\title{
İlkokul Türkçe 1 Ders Kitabının Öğretim Programındaki Temel Beceriler Açısından incelenmesi*
}

\author{
Mehmet KURUDAYIOĞLU ** \\ Taşkın SOYSAL ***
}

\begin{abstract}
Öz
Bu araştırmanın amacı “ilkokul Türkçe 1 Ders Kitabı'nın öğretim programındaki temel becerilere uygunluğu açısından incelenmesidir. Böylelikle Türkçe Öğretim Programı́nın kazandırmayı amaçladığı anahtar yetkinlikler ve temel becerilerin 2017-2018 Öğretim Yılı’nda birinci sınıflarda uygulamaya konulan Türkçe ders kitabına ne şekilde yansıdığı sınanmış olacaktır. Araştırmada 2017-2018 Öğretim Yılı’nda birinci sınıflarda okutulan Türkçe ders kitabında yer alan metin öncesi hazırlık soruları, metinler ve bu metinlere bağlı etkinlikler; 2017 Türkçe Dersi Öğretim Programı'ndaki her bir beceriye uygunluğu bakımından ayrı ayrı incelenmiştir. Nitel araştırma yöntemlerinden durum çalışması araştırmasının kullanıldığı çalışmada veriler doküman analizi yöntemiyle toplanmıştır. Çalışmanın bulguları tablolar halinde sunulup yorumlanmış ve elde edilen sonuçlar bağlamında öneriler geliştirilmiştir.
\end{abstract}

Anahtar kelimeler: Temel beceri, anahtar yetkinlik, program, Türkçe ders kitabı

\section{Examination of the First Grade Turkish Coursebook in terms of its Relevance to the Basic Skills in Turkish Language Curriculum}

\begin{abstract}
The aim of this study was to examine the "Elementary School Grade 1 Turkish Coursebook" in terms of its relevance to the basic skills in the curriculum. This way how the coursebook reflected the key competences and basic skills that the Turkish Language curriculum, which took effect in the first semester of the 2017-2018 Academic Year, aimed to teach were tested. In this study pre-text preparation questions, texts, and activities related to these texts in the Turkish coursebook, which was used in the first grade in the 2017-2018 Academic Year, were examined in terms of their compatibility with each skill in the 2017 Turkish course curriculum. In the study which used case study research which is one of the qualitative research methods, the data were collected through document analysis method. The findings of the study were presented in tabular form, interpreted, and suggestions were developed in the light of the results obtained.
\end{abstract}

Key words: Basic skill, Key competence, Curriculum, Turkish coursebook

\footnotetext{
*Bu çalışma, 17. Uluslararası Sınıf Öğretmenliği Eğitimi Sempozyumu’nda (USOS 2018) bildiri olarak sunulmuştur. ** Doç. Dr., Hacettepe Üniversitesi Eğitim Fakültesi, Türkçe ve Sosyal Bilimler Eğitimi Bölümü, Ankara, mkurudayi@hotmail.com

*** Doktora Öğrencisi, Abant İzzet Baysal Üniversitesi Eğitim Bilimleri Enstitüsü, Türkçe ve Sosyal Bilimler Eğitimi Bölümü, Bolu, taskinsoysal@gmail.com
} 


\section{Giriş}

Illkokuma ve yazma çalışmaları okul öncesi eğitimde yapılan ön hazırlığın ardından birinci sınıf itibariyle başlayan bir süreçtir. Öğrenciler, bu süreçte belirli bir plan dâhilinde ana dillerinde okuma ve yazma becerisi kazanırlar. Aile ve yakın çevrede kendiliğinden başlayan ve okul öncesinde ilkokula hazırlık temelinde yapılan çalışmalarla desteklenen dil gelişimi, ilkokul birinci sınıftan itibaren dile ait yazılı kodların çözülmeye başlanması olarak ifade edilebilecek bir zemine taşınmaktadır. Bu, bir anlamda bireylerin ana dillerini okuma ve yazma becerilerinde edinmeleri, konuşma ve dinleme becerilerinde de geliştirmeleri süreci olarak ifade edilebilir. "Insanın duygu boyutunu işlemek, düşünce gücünü geliştirmek, onu yaşadığı toplumun, kültürel ortamına katmak, her toplumun ana dilini bireylerine sevdirmesi, benimsetmesi, işlevsel ve etkili bir şekilde öğretebilmesi ile mümkündür" (Açık Önkaş, 2010: 122)

Öğrencilerin doğumdan itibaren ortaya koydukları dilsel gelişimin belirli bir sistem dâhilinde devam etmesi için ilk okuma yazma çalışmaları çerçevesi çizilmiş, derli toplu bir programa ihtiyaç duymaktadır. Bu anlamda ilköğretim Türkçe programlarını incelediğimizde programların (MEB, 2005; 2015 ve 2017) temel kaygısının öğrencilerde birtakım becerileri geliştirmek, bu sayede hem içinde yaşadıkları topluma hem de her geçen gün gelişen dünyaya ayak uyduracak bireyler olarak yetişmelerini sağlamak olduğu görülmektedir.

Günümüz dünyasında öğrencilerin kendilerine ve topluma yararlı bireyler olarak yetişmeleri için bazı temel becerilerle donanmaları gerekmektedir. Programlar (MEB, 2005; 2015 ve 2017), hedefledikleri becerilerle eleştirel ve yaratıcı düşünebilen, kendini doğru bir şekilde ifade edebilen, sağlıklı iletişim kurabilen, karşılaştığı problemlere çözüm önerileri getirebilen, girişimci bir ruha sahip ve iş birliğine açık bireyler yetiştirmeyi hedeflemektedirler. "Buna göre okullarımızda yaptırılan Türkçe öğretimi öğrencileri, anlama ve anlatma boyutunda geliştirdiği gibi günlük hayatta karşılaştıkları problemlerin çözümünde, eleştirel düşünmede, yaratıcılık becerilerinin gelişiminde, bilgi teknolojilerini tanıma ve kullanmalarında, karar verme süreçlerinde vb. onlara gerekli bilgi ve donanımı sağlayacaktır" (Temizkan, 2014: 51). Temel beceriler açısından programlara bakıldığında 2005 Ilköğretim Türkçe Dersi Öğretim Programı ve Kılavuzu'nun (1-5. Sınıflar) temel becerileri “Programın Yapısı” ana başlığına bağlı bir alt başıı olarak verdiği görülmektedir. Program'da (MEB, 2005) ulaşılması beklenen temel beceriler aşağıdaki gibidir:

- Türkçeyi doğru, güzel ve etkili kullanma,

- Eleştirel düşünme,

- Yaratıcı düşünme, 
- Iletişim,

- Problem çözme,

- Araştırma,

- Bilgi teknolojilerini kullanma,

- Girişimcilik,

- Karar verme,

- Metinler arası okuma,

- Kişisel ve sosyal değerlere önem verme (MEB, 2005: 13).

Öğretim programları; içinde yaşanılan çağın intiyaçlarına cevap verecek şekilde tasarlanmalı, bu anlamda gerekli görüldüğü durumlarda güncellemelere gidilmelidir. "Öğretim programı, yaşamda intiyaç duyulabilecek bilgi ve becerileri öngörerek, bunları belirli sürelerde öğrencilere kazandırmayı hedefler. Program içeriğinin isabetli olarak belirlenmesi, öngörünün güçlü olmasına bağlıdır. Güçlü bir öngörüye rağmen, zaman içinde ortaya çıkan gelişmeler, gündelik yaşamın farklılaşan ihtiyaçları programlarda değişikliğe gidilmesi gerektirebilir" (Güzel ve Karadağ, 2013: 46). Ülkemizde de öğretim programlarına bakıldığında 1981 yılından beri uygulanmakta olan öğretim programının 2005 yılında köklü bir değişiklikle yenilendiği görülmektedir. 2015 yılına gelindiğinde ise 2005 programı üzerinde birtakım güncellemelere gidilerek yeni bir Program (MEB, 2015) yayınlanmıştır. 2015 Türkçe Dersi (18. Sınıflar) Öğretim Programı'na temel beceriler açısından baktığımızda bu programda temel becerilerin ayrı bir başlık olarak verilmediği, "Programın Temel Yaklaşımı" başlığı altında "Türkçeyi doğru, etkili ve güzel kullanma, eleştirel ve yaratıcı düşünme, iletişim, problem çözme, araştırma, bilgi teknolojilerini kullanma, girişimcilik ve karar verme gibi temel becerilere yer verilmiştir." ifadelerinin geçtiği görülmektedir.

Ülkemizde 2017 yılı itibariyle yeni bir Program (MEB, 2017) yayınlanmış ve 2015 Programı üzerinde birtakım değişikliklere gidilmiştir. 2017 Programı'na temel beceriler açısından baktığımızda Program'da (MEB, 2017) temel becerilerin “Öğretim Programında Temel Beceriler" adıyla ayrı bir ana başlık olarak verildiğini ancak temel beceri anlayışında bir değişikliğe gidilerek temel becerilerin "anahtar yetkinlikler" bağlamında ele alındığı görülmektedir. 2017 Programı'nda yer verilen anahtar yetkinlikler aşağıdaki gibidir:

- Ana Dilde Illetişim

- Yabancı Dillerde İletişim

- Matematiksel Yetkinlik ve Bilim/Teknolojide Temel Yetkinlikler 
- Dijital Yetkinlik

- Öğrenmeyi Öğrenme

- Sosyal ve Vatandaşlıkla ilgili Yeterlilik

- İnisiyatif Alma ve Girişimcilik

- Kültürel Farkındalık ve Ifade (MEB, 2017: 6).

Programda (MEB, 2017) bu anahtar yetkinliklerin belirlenmesinde Avrupa Yeterlilikler Çerçevesi ile uyumlu şekilde hazırlanan Türkiye Yeterlilikler Çerçevesi'nin esas alındığı vurgulanmış, ayrıca temel becerilerin ayrı bir başlık olarak aktarılmamasının sebebinin becerilerin, kazanımların içerisinde ve kazanımların altındaki açıklamalarda örtük olarak verilmiş olması sebebiyle olduğu açıklaması yapılmıştır. Her ne kadar programda birtakım becerilerin öğrencilere aktarılması yoluyla "millî, manevi, evrensel değerlere sahip; hem akademik hem de sosyal anlamda başarılı olabilen; teknolojik gelişmelere uyum sağlayabilen; kendisine, toplumuna ve farklı kültürlere karşı yüksek düzeyde farkındalıkla saygı duymayı başarabilen, hayata hazır, mutlu ve sağlıklı bireyler olarak yetişmelerini sağlamak" (MEB, 2017: 5) vurgusu yapılmış olsa da söz konusu beceri ve yeterliliklerin öğrencilere aktarılacağı yegâne araç ders kitaplarıdır. Her sınıf düzeyinde ders kitaplarına seçilecek metinler, metinlere bağlı hazırlık çalışmaları ve etkinlikler temel becerileri barındırdıkları ölçüde öğrenciler bu becerilerle donanacaklardır. "Temel becerileri geliştirme amaçlı hazırlanmış her etkinlik aynı zamanda öğrencilerin dil becerilerini de geliştirecektir" (Kurudayıoğlu ve Çetin, 2015: 12). "Türkçe öğretiminde, hedeflenen becerilere ulaşma doğrultusunda en önemli materyal, Türkçe ders kitaplarıdır. Ülkemiz koşulları göz önünde alındığında tüm öğrencilerin rahatlıkla ulaşabildiği bu araçların, eğitim programının hedef, içerik, eğitim durumları ve ölçme-değerlendirme ögelerini barındıran özelliklere sahip olması gerekmektedir” (Baş ve İnan Yıldız, 2014: 140).

Bu çalışmanın amacı, 2017 Türkçe Dersi Öğretim Programı'na (1, 2, 3, 4, 5, 6, 7 ve 8. Sınıflar) göre Milli Eğitim Bakanlığı tarafından hazırlanan ve 2017-2018 Öğretim Yılı'nda 1. sınıflarda okutulmaya başlanan İlkokul Türkçe 1 Ders Kitabı'nın programda aktarılan yetkinlik ve beceriler açısından incelenmesidir. Bu sayede programın öğrencilere kazandırmayı amaçladığı yetkinlik ve becerilere ders kitabında ne şekilde yer verildiği belirlenmiş olacaktır.

Çalışmanın tamamlanması aşamasında Türkçe dersi öğretim programında güncellemeye gidilerek yeni bir program (MEB, 2018) yayınlanmıştır. Yapılan incelemede anahtar yetkinlikler ve temel beceriler açısından 2017 Programı ile 2018 Programı arasında herhangi bir fark olmadığı görülmüş, çalışma en başta planlandığı şekilde yürütülmüştür. 


\section{Yöntem}

Çalışma, nitel bir durum çalışması araştırmasıdır. "Durum çalışması araştırması, araştırmacının gerçek yaşam, güncel sınırlı bir sistem (bir durum) ya da belli bir zaman içerisindeki çoklu sınırlandırılmış sistemler (durumlar) hakkında çoklu bilgi kaynakları (örneğin gözlemler, mülakatlar, görsel-işitsel materyaller ve dokümanlar ve raporlar) aracılığıyla detaylı ve derinlemesine bilgi topladığı, bir durum betimlemesi ya da durum temaları ortaya koyduğu nitel bir yaklaşımdır" (Aydın, 2016: 97).

Araştırmanın veri toplama tekniği doküman analizidir. Yıldırım ve Şimşek (2016) doküman analizini, hedeflenen olgu veya olgular hakkında bilgi içeren yazılı materyallerin analizi şeklinde ifade etmişlerdir. "Dokümanlar, yazılı halde bulunan metinlerden oluşan her tür doküman, görüntü ve ses kayıtları ile diğerleri kapsamında yer alan objeler, kalıntılar makro ve mikro düzeydeki veriler olarak gruplandırııı" (Yıldırım ve Şimşek, 2013: 223). Doküman incelemesinde "Araştırmaya konu olan olay, birey ya da nesne, kendi koşulları içinde ve olduğu gibi tanımlanmaya çalışılır. Onları herhangi bir şekilde değiştirme, etkileme çabası gösterilmez. Bilinmek istenen şey vardır ve oradadır. Önemli olan, onu uygun biçimde gözleyip belirleyebilmektir" (Karasar, 2008: 77).

Araştırmanın inceleme nesnesi, 2017-2018 Öğretim Yılı’nda birinci sınıflarda okutulan Milli Eğitim Bakanlığı Yayınları’na ait “ilkkokul Türkçe 1 Ders Kitabı”dır. IIlkokul Türkçe 1 Ders Kitabı sekiz ayrı üniteden oluşmaktadır ve inceleme nesnesi olan kitap 5, 6, 7 ve 8. temaları içermektedir. Buna göre,

5. Tema: Çocuk Dünyası

6. Tema: Doğa ve Evren

7. Tema: Milli Mücadele ve Atatürk

8. Tema: Bilim ve Teknoloji'dir.

Her tema kendi içerisinde bir dinleme metni, üç okuma metni ve bir serbest okuma metninden oluşmaktadır. Serbest okuma metinleri hariç her metnin başlangıcında bir hazırlık sorusuna yer verilmiş, ardından metin ve metinlere bağı etkinlikler sıralanmıştır. Metinlere bağlı etkinliklerin sayısında herhangi bir ortaklık gözetilmemiş, metinlerde en az dört en fazla on etkinliğe yer verilmiştir. Araştırmacılar kitapta yer alan hazırlık soruları, metinler ve metinlere bağlı etkinlikleri ana dilde iletişim, yabancı dillerde iletişim, matematiksel yetkinlik ve bilim/teknolojide temel yetkinlikler, dijital yetkinlik, öğrenmeyi öğrenme, sosyal ve vatandaşlıkla ilgili yeterlilik, inisiyatif alma ve girişimcilik, kültürel farkındalık ve ifade yetkinliklerine göre incelemişlerdir.

Inceleme sonunda her iki araştırmacının bulguları karşılaştırılarak ortak bir çerçeve ortaya konulmuştur. Araştırmacıların kendi aralarındaki uyumlarında Bilgin'in (2000) “Kodlayıcının güvenirliği farklı kodlayıcıların aynı metni aynı şekilde kodlamalarını gerektirir." şeklindeki görüşü esas alınmıştır. 


\section{Bulgular ve Yorum}

Çalışmanın bu bölümünde İlkokul Türkçe 1 Ders Kitabı'nda yer alan hazırlık soruları, metinler ve metinlere bağlı etkinliklerde yer alan anahtar yetkinlik ve beceriler ayrı ayrı tablolar hâline getirilmiş, her bir yetkinlik ve becerinin sıklıkları ortaya konulmuştur. Anahtar yetkinliklerden "ana dilde iletişim" inceleme nesnesi olan İlkokul Türkçe 1 Ders Kitabı'nın bir ana dili kitabı olması sebebiyle her ne kadar aşağıdaki tablolarda sıklık bakımından ortaya konulmuş olsa da tablolara bağlı yorumlarda üzerinde durulmamıştır. Çünkü ana dilde iletişim anahtar yetkinliği kitabın doğası gereği zorunlu olarak bulunmak durumundadır.

Hazırlık Sorularında Yer Alan Yetkinlik ve Becerilere İlişkin Bulgular ve Yorum

Hazırlık soruları, kitapta yer alan her bir metinden önce öğrencilerin konuya ilişkin hazır bulunuşluklarını ölçmeyi ve ayrıca konuya dikkat çekerek öğrencilerde okuma isteği uyandırmayı sağlayacak bir şekilde tasarlanmıştır. Dinleme metinleri de dâhil olmak üzere her metin için bir hazırlık sorusuna yer verilmiştir.

Tablo 1. Hazırlık Sorularında Yer Alan Anahtar Yetkinlikler

\begin{tabular}{|c|c|c|c|c|c|c|c|c|c|}
\hline & \multirow[b]{2}{*}{ Hazırlık Soruları } & \multicolumn{8}{|c|}{ Anahtar Yetkinlikler } \\
\hline & & 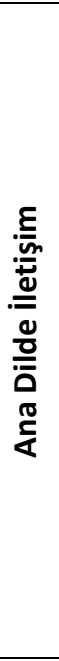 & 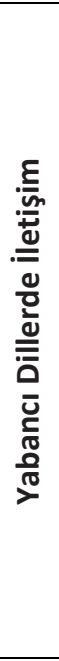 & 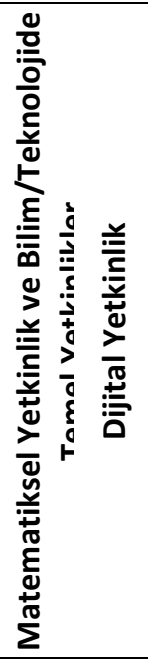 & 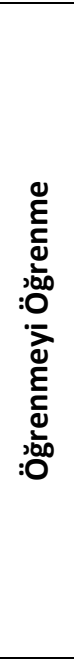 & 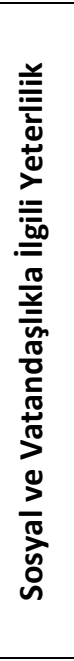 & 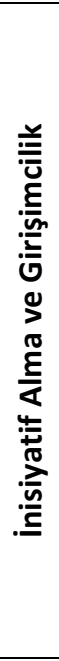 & 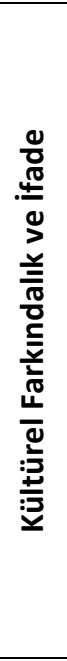 & $\begin{array}{l}\frac{\varepsilon}{\pi} \\
\frac{0}{0} \\
\circ\end{array}$ \\
\hline \multirow{4}{*}{ 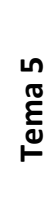 } & Dinleme Metni & 1 & & & & & 1 & & 2 \\
\hline & Okuma Metni & 1 & & & & & 1 & & 2 \\
\hline & Okuma Metni & 1 & & & & & 1 & & 2 \\
\hline & Okuma Metni & 1 & & & & & 1 & & 2 \\
\hline \multirow{4}{*}{ 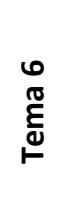 } & Dinleme Metni & 1 & & & & & 1 & & 2 \\
\hline & Okuma Metni & 1 & & & & & 1 & & 2 \\
\hline & Okuma Metni & 1 & & & & & 1 & & 2 \\
\hline & Okuma Metni & 1 & & & & & 1 & & 2 \\
\hline \multirow{3}{*}{ 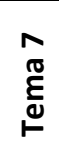 } & Dinleme Metni & 1 & & & & & 1 & 1 & 3 \\
\hline & Okuma Metni & 1 & & & & & 1 & & 2 \\
\hline & Okuma Metni & 1 & & & & & 1 & 1 & 3 \\
\hline
\end{tabular}


ilkokul Türkçe 1 Ders Kitabının Öğretim Programındaki Temel Beceriler Açısından İncelenmesi

\begin{tabular}{|c|c|c|c|c|c|c|c|c|c|c|}
\hline & Okuma Metni & 1 & & 1 & & & & 1 & 1 & 4 \\
\hline \multirow{4}{*}{$\begin{array}{l}\infty \\
\mathbb{0} \\
\stackrel{0}{\varrho}\end{array}$} & Dinleme Metni & 1 & & 1 & & & & 1 & & 3 \\
\hline & Okuma Metni & 1 & & & 1 & & & 1 & & 3 \\
\hline & Okuma Metni & 1 & & 1 & & & & 1 & & 3 \\
\hline & Okuma Metni & 1 & & & & & & 1 & & 2 \\
\hline Toplam & & 16 & 0 & 3 & 1 & 0 & 0 & 16 & 3 & 39 \\
\hline
\end{tabular}

Tablo 1 incelendiğinde tüm kitapta yer alan toplam on altı hazırlık sorusunda "yabancı dillerde iletişim", "öğrenmeyi öğrenme" ile "sosyal ve vatandaşlıkla ilgili yeterlilik" anahtar yetkinliklerine hiç yer verilmediği görülmektedir. Yabancı dillerde iletişim anahtar yetkinliğinin bir ana dili kitabında olmamasının doğal karşılanabileceği düşünülebilir ancak "yabancı dillere karşı olumlu tutum, kültürel çeşitliliğin değerini bilme, dillere karşı ilgi, merak ve kültürler arası iletişime karşı farkındalık" (MEB, 2017: 6) gibi önemli alanlara temas etmesi bakımından bu anahtar yetkinliğe de yer verilmesinin gerekli olabileceği düşünülebilir. Bununla birlikte kişinin güçlü ve zayıf yönlerini bilerek kendi öğrenmesini ona göre yapılandırması olarak özetlenebilecek öğrenmeyi öğrenme anahtar yetkinliği ile sosyal hayata verimli katılımı sağlayacak, aynı zamanda vatandaşlıkla ilgili görev ve sorumlulukların bilincinde olacak bireyler olarak yetişmeleri bakımından öğrenciler için önem arz eden sosyal ve vatandaşıkla ilgili yeterliliklere de hazırlık soruları içerisinde hiç yer verilmemiş olduğu dikkat çekmektedir.

"Dijital yetkinlik" bakımından Tablo 1'e bakıldığında bu anahtar yetkinliğe bütün kitapta sadece bir kez sekizinci temada yer verildiği görülmektedir. Sekizinci temanın ilk okuma metnine bağlı hazırlık sorusunda geçen "Süper bir bilgisayarın olsa onunla neler yapmayı isterdin?" ifadelerinin "bilgi iletişim teknolojisi içinde bilgiye erişim ve bilginin değerlendirilmesi, saklanması, üretimi, sunulması ve alışverişi için bilgisayarların kullanılması, ayrıca internet aracılığıyla ortak ağlara katılım sağlanması ve iletişim kurulması gibi temel beceriler" (MEB, 2017: 6) açıklamalarına temas ettiği görülmektedir. İçinde yaşadığımız yüzyııın bir gereği olarak kitabın tamamında, özellikle de bilim ve teknoloji temasına bağı ı̈ç ayrı hazırlık sorusunda dijital yetkinliğe yalnızca bir kez temas edilmiş olmasının yetersiz olduğu düşünülebilir.

"Matematiksel yetkinlik ve bilim/teknolojide temel yetkinlikler" ile "kültürel farkındalık ve ifade" anahtar yetkinlikleri bakımından Tablo 1 incelendiğinde her iki anahtar yetkinliğe toplamda üçer kez yer verildiği görülmektedir. Dil ve kültürün bir bütünün ayrılmaz parçaları olması bakımından on altı hazırlık sorusunda kültürel farkındalığa yalnızca üç kez temas edilmiş olması dikkate değerdir. Matematiksel yetkinlik ve bilim/teknolojide temel yetkinlikler anahtar yetkinliğine bakıldığında ise “Matematiksel yetkinlik, düşünme (mantıksal ve uzamsal düşünme) ve sunmanın (formüller, modeller, kurgular, grafikler ve tablolar) matematiksel modlarını farklı derecelerde kullanma beceri ve isteğini içermektedir" (MEB, 2017: 6). Ayrıca "Bilim ve teknolojideki yetkinlik ise doğal dünyayı, fen ve teknolojinin etkisini anlamanın yanında doğanın temel prensiplerini, temel bilimsel kavramları, 
prensipleri ve metotları, teknoloji ve teknolojik ürünleri ve yöntemleri bilmeyi içermekte olup bireyin bilimsel araştırmanın temel vasıflarını tanımasına ve sonuçları tartışma ve bunları aydınlatmak için akıl yürütme yeteneğine sahip olmasına odaklanmaktadır" (MEB, 2017: 6) açıklamalarından hareketle öğrencilerin ana dilinde matematiksel düşünme becerisi kazanmanın yanında fen ve teknolojinin etkisini anlama ve kavramaları bakımından önemi ortaya konulmuştur. Buna rağmen bu anahtar yetkinliğe beşinci ve altıncı temada hiç yer verilmemiş; yedinci temada yalnızca bir, sekizinci temada ise iki kez yer verildiği tespit edilmiştir.

“inisiyatif Alma ve Girişimcilik” anahtar yetkinliğine bakıldığında diğer tüm anahtar yetkinliklerden farklı olarak bütün hazırlık sorularında bu yetkinliğe yer verildiği görülmektedir. Bunun başlıca sebebinin öğrencilere sorulan soruların "Bireyin düşüncelerini eyleme dönüştürme" (MEB: 2017: 6) becerisini geliştirmeye katkı sunacak nitelikte olmasıdır. Öğrenciler, kendilerine sorulan sorulara cevap vermek için risk almak, yaratıcı ve yenilikçi düşünerek kendilerini bu şekilde ifade etmek durumundadırlar. Bu açıdan öğrenciler, inisiyatif alma ve girişimcilik anahtar yetkinliğiyle sıkça karşılaşarak bu becerilerini geliştirme yönünde önemli adımlar atmış olacaklardır.

\section{Metinlerde Yer Alan Yetkinlik ve Becerilere Ilişkin Bulgular ve Yorum}

Illkokul Türkçe 1 Ders Kitabı'nda bulunan her bir temada bir dinleme metni, üç okuma metni ve bir serbest okuma metni olmak üzere beş ayrı metin bulunmaktadır. Metinlerin temas ettiği anahtar yetkinlikler birer kez sayılmıştır çünkü metinler kendi içerisinde bütünlük arz etmektedir. Aşağıdaki tabloda bu metinlerde yer alan anahtar yetkinliklerin sıklıkları verilmiştir:

Tablo 2. Metinlerde Yer Alan Anahtar Yetkinlikler

\begin{tabular}{|c|c|c|c|c|c|c|c|c|c|}
\hline & \multirow[b]{2}{*}{ Metinler } & \multicolumn{8}{|c|}{ Anahtar Yetkinlikler } \\
\hline & & 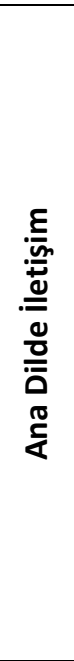 & 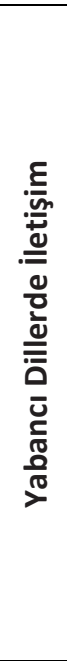 & 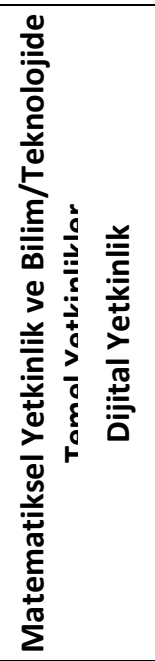 & 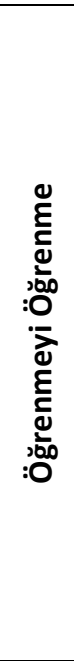 & 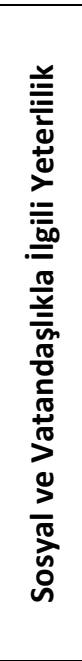 & 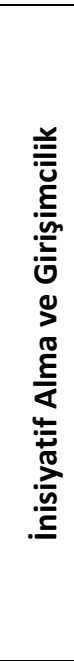 & 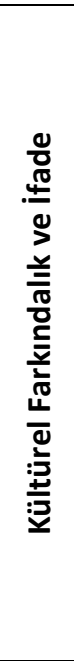 & $\begin{array}{l}\frac{\varepsilon}{\pi} \\
\frac{0}{0} \\
\vdash\end{array}$ \\
\hline \multirow{5}{*}{ 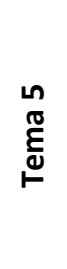 } & Dinleme Metni & 1 & & 1 & & & & & 2 \\
\hline & Okuma Metni & 1 & & 1 & & & & 1 & 3 \\
\hline & Okuma Metni & 1 & & 1 & & & 1 & 1 & 4 \\
\hline & Okuma Metni & 1 & & 1 & & & & & 2 \\
\hline & Serbest Okuma Metni & 1 & & 1 & & & & 1 & 3 \\
\hline
\end{tabular}


İlkokul Türkçe 1 Ders Kitabının Öğretim Programındaki Temel Beceriler Açısından İncelenmesi

\begin{tabular}{|c|c|c|c|c|c|c|c|c|c|c|}
\hline \multirow{5}{*}{$\begin{array}{l}0 \\
\mathbb{R} \\
\stackrel{\mathbb{E}}{\sigma}\end{array}$} & Dinleme Metni & 1 & & 1 & & & & & & 2 \\
\hline & Okuma Metni & 1 & & 1 & & & & 1 & & 3 \\
\hline & Okuma Metni & 1 & & 1 & & & & & & 2 \\
\hline & Okuma Metni & 1 & & 1 & & & & & 1 & 3 \\
\hline & Serbest Okuma Metni & 1 & & 1 & & & & & 1 & 3 \\
\hline \multirow{5}{*}{ 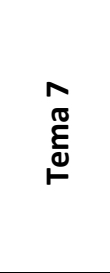 } & Dinleme Metni & 1 & & 1 & & & 1 & & & 3 \\
\hline & Okuma Metni & 1 & & 1 & & 1 & 1 & & 1 & 5 \\
\hline & Okuma Metni & 1 & & 1 & & & 1 & & 1 & 4 \\
\hline & Okuma Metni & 1 & & 1 & & & 1 & & 1 & 4 \\
\hline & Serbest Okuma Metni & 1 & & 1 & & & 1 & & 1 & 4 \\
\hline \multirow{5}{*}{$\begin{array}{c}\infty \\
\mathbb{0} \\
\stackrel{E}{0} \\
上\end{array}$} & Dinleme Metni & 1 & & 1 & & & & & & 2 \\
\hline & Okuma Metni & 1 & & 1 & 1 & & & & 1 & 4 \\
\hline & Okuma Metni & 1 & & 1 & 1 & & & & 1 & 4 \\
\hline & Okuma Metni & 1 & & 1 & & 1 & & & 1 & 4 \\
\hline & Serbest Okuma Metni & 1 & & 1 & & & & & & 2 \\
\hline Toplam & & 20 & 0 & 20 & 2 & 2 & 5 & 2 & 12 & 63 \\
\hline
\end{tabular}

Tablo 2 incelendiğinde "Yabancı Dillerde İletişim" anahtar yetkinliğine kitapta yer alan hiçbir metinde temas edilmediği, buna karşın "Matematiksel Yetkinlik ve Bilim/Teknolojide Temel Yetkinlikler" anahtar yetkinliğinin tüm metinlerde yer aldığı görülmektedir. "Yabancı dillere karşı olumlu tutum, kültürel çeşitliliğin değerini bilme, dillere karşı ilgi, merak ve kültürler arası iletişime karşı farkındalık" (MEB: 2017: 6) gibi açılardan önem arz eden yabancı dillerde iletişim anahtar yetkinliğinin kitapta hiç yer almıyor oluşu dikkat çekicidir. Matematiksel yetkinlik ve bilim/teknolojide temel yetkinliklerin kitabın tamamında yer alması metinlerin öğrencilerin seviyesine bağlı olarak güçlü görsellerle donatılması sebebiyledir. Öğrencilerin metinlere bağlı görsellerde formüller, modeller, kurgular, grafikler ve tablolar vasıtasıyla mantıksal ve uzamsal düşünmeleri, aynı zamanda doğal dünyayı anlamaları bakımından önemli olan bu yetkinliğe tüm metinlerde temas ediliyor oluşu olumlu bir durum olarak karşımıza çıkmaktadır.

"Dijital Yetkinlik", “Öğrenmeyi Öğrenme” ile "İnisiyatif Alma ve Girişimcilik” anahtar yetkinlikleri açısından Tablo 2'ye bakıldığında her üç anahtar yetkinliğe de tüm kitapta yalnızca ikişer kez yer verildiği görülmektedir. Bilgi çağında bilgi toplumu açısından oldukça önemli olan dijital yetkinlik, kişinin kendi öğrenmesini yapılandırması bakımından önem arz eden öğrenmeyi öğrenme ve düşünceleri eyleme dönüştürme becerisini destekleyen inisiyatif alma ve girişimcilik anahtar yetkinliklerinin sayısının yirmi ayrı metinde yalnızca ikiyle sınırlı kalması dikkat çekicidir.

"Sosyal ve Vatandaşııkla İlgili Yeterlilik" açısından Tablo 2 incelendiğinde Program'da (MEB, 2017) yer alan "aynı demokratik prensiplere saygı gibi ulusal bağılığı sağlamak için gerekli olan ve paylaşılan değerlere anlayış ve saygı göstermek kadar sorumluluk hissini ortaya koymak" (MEB, 2017: 6) ifadelerine bağlı olarak "Milli Mücadele ve Atatürk" temasında bu yetkinliğe her metinde bir kez, 
toplamda beş kez temas edildiği ancak bunun dışındaki herhangi bir metinde sosyal ve vatandaşlıkla ilgili yeterliliğe yer verilmediği görülmektedir.

"Kültürel Farkındalık ve İfade" anahtar yetkinliği açısından Tablo 2 incelendiğinde bu anahtar yetkinliğe yirmi ayrı metinde toplamda on iki kez temas edildiği görülmektedir. Dil ve kültürün iç içeliğinden yola çıkılarak bu anahtar yetkinliğin de en az ana dilde iletişim anahtar yetkinliği kadar olması söz konusu olabilirdi. Ancak on iki sayısıyla bu yetkinliğin ana dilde iletişim yetkinliğinin yarısından biraz fazla olduğu görülmektedir.

Metinlere Bağlı Etkinliklerde Yer Alan Yetkinlik ve Becerilere Ilişkin Bulgular ve Yorum

Tablo 3. Metinlere Bağlı Etkinliklerde Yer Alan Anahtar Yetkinlikler

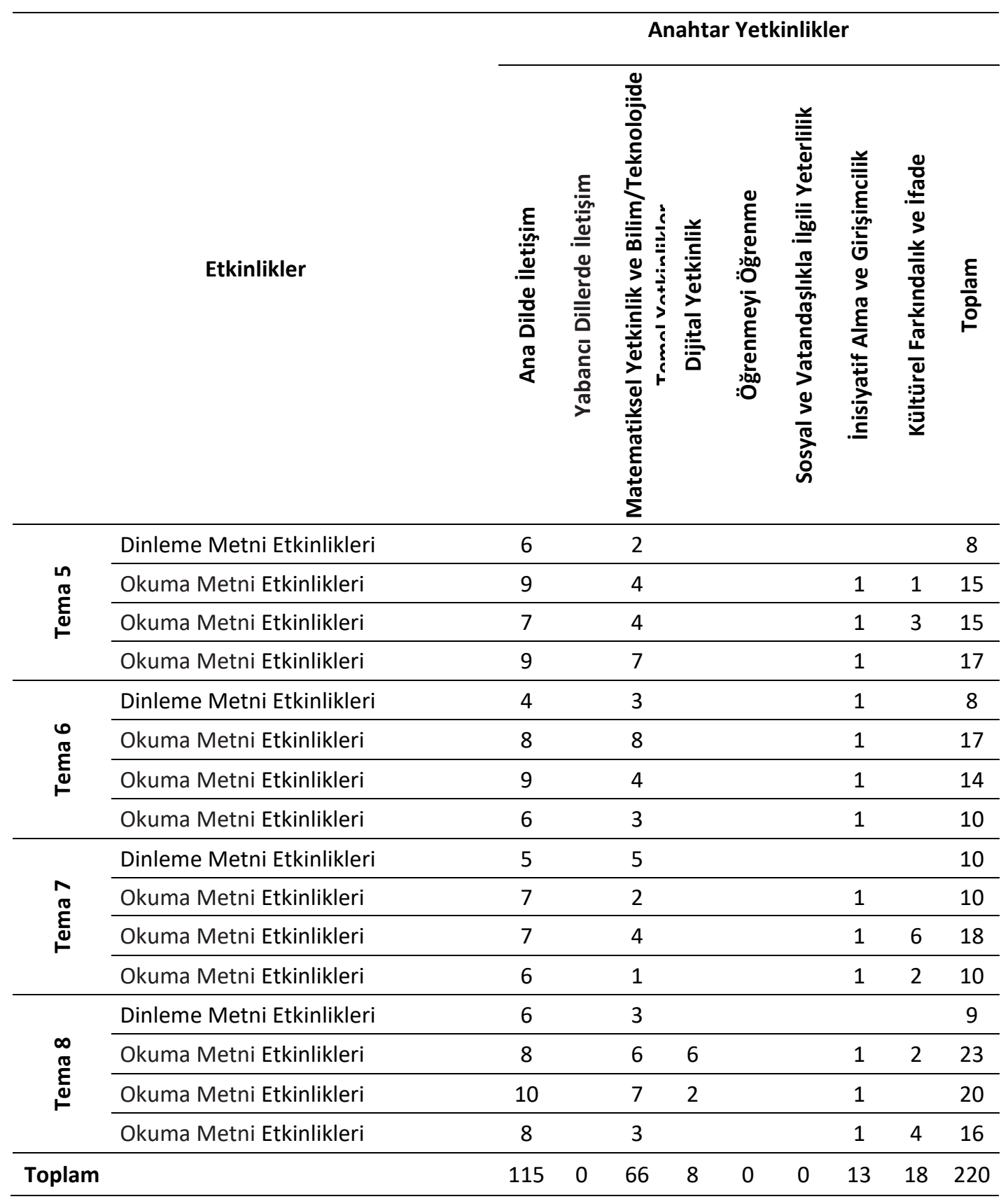


İlkokul Türkçe 1 Ders Kitabının Öğretim Programındaki Temel Beceriler Açısından İncelenmesi

Tablo 3 incelendiğinde "Yabancı Dillerde Iletişim" anahtar yetkinliğinin hiçbir etkinlikte yer almadığı görülmektedir. Burada üzerinde durulması gereken nokta, yabancı dillerde iletişim anahtar yetkinliğinin yalnızca yabancı dilde iletişim kurma olmadığı, aynı zamanda "yabancı dillere karşı olumlu tutum, kültürel çeşitliliğin değerini bilme, dillere karşı ilgi, merak ve kültürler arası iletişime karşı farkındalığı" (MEB, 2017: 6) ifade ettiğidir. Bu nedenle bu anahtar yetkinliğe inceleme nesnesi olan kitapta hiçbir etkinlikte yer verilmemiş olması dikkat çekmektedir. Aynı şekilde "Bireyin yaşamı boyunca öğrenmeyi başarma ve sürdürmede motivasyonu" (MEB, 2017: 6) açısından oldukça önemli olan “Öğrenmeyi Öğrenme” ve "Kişisel, kişiler arası, kültürel ve kültürler arası yeterliliği, ayrıca sosyal ve çalışma yaşamına bireylerin etkili ve yapıcı yolla katılması için bireyleri donatan davranışın tüm formlarını ve gereken yerlerde fikir ayrılıklarını çözmeyi sağlayacak çeşitli davranışlarla bütünüyle donanmayı" içermesi yönüyle büyük önem arz eden "Sosyal ve Vatandaşlıkla ilgili Yeterlilik" anahtar yetkinliğine de hiçbir etkinlikte temas edilmemiş olması dikkate değerdir.

"Dijital Yetkinlik" bakımından Tablo 3 incelendiğinde bu anahtar yetkinliğe yalnızca sekizinci temada sekiz kez temas edildiği, bunların altı tanesinin birinci okuma metninde kalan iki tanesinin de ikinci okuma metninde olduğu görülmektedir. Bilim ve teknoloji teması olan sekizinci temada dijital yetkinliğe temas edilmesi önemlidir ancak bu yetkinliğe sekizinci temanın tüm metinlerinde yer verilmemesi; bunun yanında beş, altı ve yedinci temalarda bu anahtar yetkinliğe hiç temas edilmemiş olması göze çarpmaktadır.

"Inisiyatif Alma ve Girişimcilik" anahtar yetkinliği bakımından Tablo 3'e bakıldığında dinleme metinlerinin de dâhil olduğu toplam on altı metnin on üçüne bağlı etkinliklerde bu anahtar yetkinliğinde birer kez temas edildiği görülmektedir. Etkinliklerde öğrencilere yöneltilen bir soru yoluyla onların düşüncelerinin eyleme geçirilmesi, böylece girişimci davranışlar sergilemeleri esası söz konusudur. Bu anahtar yetkinliğin belirli temalarda yığılma göstermeden kitabın tamamında yer alması ve hemen hemen tüm metinlerde bu yetkinliğe değinilmiş olması olumlu bir durum olarak karşımıza çıkmaktadır.

"Kültürel Farkındalık ve ifade" anahtar yetkinliği açısından Tablo 3 incelendiğinde bu anahtar yetkinliğe yüz on beş etkinlikte yalnızca on sekiz kez temas edildiği görülmektedir. Dil ve kültürün birbirinin tamamlayııısı oldukları göz önünde bulundurulduğunda kültürel farkındalık ve ifade anahtar yetkinliğinin kitabın tamamı için yetersiz kaldığı söylenebilir.

"Matematiksel Yetkinlik ve Bilim/Teknolojide Temel Yetkinlikler" bakımından Tablo 3 incelendiğinde bu anahtar yetkinliğe yüz on beş etkinliğin altmış altısında yer verildiği görülmektedir. Inceleme nesnesi olan kitapta etkinliklerin birçoğunun anlamayı destekleyecek nitelikteki çeşitli görsellerle birlikte verildiği görülmüştür. Görseller vasıtasıyla çocukların mantıksal ve uzamsal 
düşünme becerilerinin gelişebileceği noktasından hareketle bu anahtar yetkinliğin sayıca fazla olması olumlu bir durum olarak karşımıza çıkmaktadır.

\section{Sonuç ve Öneriler}

Yapılan incelemede IIlkokul Türkçe 1 Ders Kitabı hazırlanırken gerek metinlerde ve gerekse metinlere bağlı hazırlık çalışmaları ve etkinliklerde anahtar yetkinliklerin ve temel becerilerin kitapta yer almasına yönelik herhangi bir planlamaya gidilmediği görülmüştür. Ana dilde iletişim anahtar yetkinliğinin zorunlu olarak bulunması dışında diğer yetkinlik ve beceriler sayıca az olmakla birlikte temalar arasında da dengeli bir şekilde dağıtılmamıştır. Yetkinlik ve becerilerin öğrencilere kazandırılmasının programların temel iddiası olduğundan hareketle temalar, metinler, etkinlikler ve hazırlık çalışmaları arasında anahtar yetkinliklerin belirli bir plana göre dağıtılması gerekmektedir.

2017 yılında yenilenen diğer ders programları gibi Türkçe Dersi Öğretim Programı da anahtar yetkinlikler bağlamında öğrencilerin birtakım yeterlilik ve becerileri geliştirmesini hedeflemektedir. Programların hedeflerini yansıtacakları yerin ders kitapları olması sebebiyle Türkçe ders kitaplarının da diğer ders kitapları gibi anahtar yetkinlikler bağlamında temel becerileri geliştirmesi beklenmektedir. Bütün sınıf düzeylerine yönelik mevcut ders kitapları ile beraber Türkçe ders kitapları da anahtar yetkinlikler ve temel beceriler açısından gözden geçirilerek güncellenmeli ve yeni yazılacak Türkçe ders kitaplarının anahtar yetkinliklerin ve temel becerilerin geliştirilmesine yönelik metin ve etkinliklere dengeli bir şekilde yer vermesi sağlanmalıdır. Bu açıdan kitaplara konulacak her bir metin, bu metinlere bağlı hazırlık çalışmaları ve etkinlikler titizlikle işlenmeli, programların öğrencilere aktarmayı hedeflediği anahtar yetkinlikler ve temel beceriler kazandırılmaya çalışılmalıdır.

\section{Kaynaklar}

Baş, B. ve İnan Yıldız, F. (2014). Illkokul Türkçe ders kitaplarının resim-metin ilişkisi açısından öğretmen görüşlerine göre değerlendirilmesi. Mustafa Kemal Üniversitesi Sosyal Bilimler Enstitüsü Dergisi, 11(28), 139-51.

Açık Önkaş, N. (2010). Ana dili öğretimine yeni yaklaşımlar. Muğla Üniversitesi Sosyal Bilimler Enstitüsü Dergisi, 24, 121-128.

Bilgin, N. (2000). İçerik analizi. İzmir: Ege Üniversitesi Edebiyat Fakültesi Yayınları.

Creswell, J. W. (2013). Nitel araştırma yöntemleri. (3. baskıdan çeviri). (Çev. Ed.: Mesut Bütün, Selçuk Beşir Demir). Ankara: Siyasal Kitabevi.

Güzel, A. ve Karadağ, Ö. (2013). Anlatma becerileri açısından “Türkçe Dersi Öğretim Programı (6, 7, 8. Sınıflar)”na eleştirel bir bakış. Ana Dili Eğitimi Dergisi, 1(1), 45-52.

Karasar, N. (2008). Bilimsel araştırma yöntemi. Ankara: Nobel Yayıncılık.

Kurudayıoğlu, M. ve Çetin, Ö. (2015). Temel beceriler ve Türkçe öğretimi. Ana Dili Eğitimi Dergisi, 3(3), 1-19.

MEB. (2005). Ilköğretim Türkçe dersi öğretim programı ve kılavuzu (1-5. sınıflar). Ankara: Millî Eğitim Bakanlığı.

MEB. (2015). Türkçe dersi (1-8. sınıflar) öğretim programı. Ankara.

MEB. (2017). Türkçe dersi ögrretim programı (ilkokul ve ortaokul 1, 2, 3, 4, 5, 6, 7 ve 8. sınıflar). Ankara.

MEB. (2018). Türkçe dersi öğretim programı (ilkokul ve ortaokul 1, 2, 3, 4, 5, 6, 7 ve 8. sınıflar). Ankara. 
Temizkan, M. (2014). Ortaokul Türkçe ders kitaplarının Türkçe dersi öğretim programındaki temel beceriler açısından incelenmesi. Ana Dili Eğitimi Dergisi, 2(1), 49-72.

Yıldııım, A. ve Şimşek, H. (2013). Sosyal bilimlerde nitel araştırma yöntemleri. Ankara: Seçkin Yayınları.

Yıldırım, A. ve Şimşek, H. (2016). Sosyal bilimlerde nitel araştırma yöntemleri. Ankara: Seçkin Yayınları.

\section{Extended Abstract \\ Introduction}

Elementary reading and writing studies are initial steps through which students acquire reading and writing skills in their mother tongue according to a certain plan. The first literacy curriculum requires an established and rigorous program in order for students to continue their linguistic development which started immediately after birth within a certain system. In this sense, when we examine the elementary education Turkish course curriculum, it is seen that the main concern of the programs is to develop the skills of the students and to enable them to grow up as individuals who can live in the developing world and to meet the needs of developing world.

Today, students need to be equipped with some basic skills in order to grow up to help themselves and society. The programs aim to educate individuals who have critical and creative thinking skills, who can express themselves correctly, who can establish healthy communication, who can offer solutions to the problems they face, who have an entrepreneurial spirit and who are open to cooperation.

The aim of this study is to examine the elementary school Turkish 1 course book in terms of the competences and skills stated in the 2017 Turkish course Grades 1-8 curriculum which was prepared by the Ministry of National Education and took effect in the $1^{\text {st }}$ grade in the 2017-2018 school year. The purpose was to determine how the competences and skills that the program aimed to give to students were included in the course book.

During the course of the study, a new program took effect to update the existing Turkish course curriculum. In the examination made, it was seen that there was no difference between the 2017 Program and the 2018 Program in terms of key competences and basic skills, and the study was carried out as originally planned.

\section{Method}

The study is a qualitative case study. The data collection technique of the research is document analysis. The object of examination of the research is the "Elementary School Turkish 1 Course Book" published by the Ministry of National Education for the 2017-2018 academic year. Researchers subjected the preparatory questions, texts and text related activities in the book to content analysis in terms of communication in mother tongue, communication in foreign languages, mathematical competence and basic competences in science / technology, digital competence, learning to learn, social and citizenship competence, taking initiative and entrepreneurship, cultural awareness and expressional competence. At the end of the study, the findings of both researchers were compared and a common framework was established.

Result

When examining the key competences in the preparatory questions, it was seen that there were no key competences about "communication in foreign languages", "learning to learn" and "social and citizenship competence" in a total of sixteen preliminary questions in the entire book. It may be considered natural that communication in foreign languages key competence may not be included in a native language course book, but it also may be considered that it is necessary to include this key competence in terms of "positive attitude towards foreign languages, knowledge of cultural diversity, interest in languages, curiosity and awareness of intercultural communication awareness". It was also seen that "social and citizenship" competence was not included in the preparatory questions. The finding that this key competence was not included is noteworthy because students are expected to grow up as individuals who are conscious of their responsibilities and the duties related to citizenship and at the same time provide productive participation in social life having learned this key competence which can be summarized as individuals' knowing their own strengths and weaknesses and configuring their own learning.

In the review, in terms of "digital competence", it was seen that this key competence took place in only the eighth theme in the book. The question "What would you like to do with a supercomputer?" which takes place as a preparatory question related to the first reading text of the $8^{\text {th }}$ theme is related to the statement "basic skills such as information access in information communication technology and the use of computers for the evaluation, storage, production, presentation and exchange of information, participation in common networks via the internet, and communicate". It may be thought that even though this is a necessity of the century we live in, the fact that the topic was dwelled upon only once shows that the book is inadequate in this respect. 
It was also seen that the key competences of "mathematical competence and basic competences in science / technology" and "cultural awareness and expression" were included three times in total. It is worth noting that "cultural awareness" was included only three times in the sixteen preparatory questions as language and culture are inseparable parts of one whole. When "mathematical competence" and "basic competences in science / technology" are viewed as key competences, "mathematical competence" includes the ability and the desire to use mathematical modes at different levels of thinking (logical and spatial thinking) and presentation (formulas, models, fictions, graphics and tables). Competence in "science and technology" involves learning the basic principles of nature, basic scientific concepts, principles and methods, technology and technological products and methods as well as understanding the natural world, the effects of science and technology, and focuses on understanding the basic principles of scientific research and the reasoning ability. From this point of view, the findings revealed the importance of gains in students' mathematical thinking skills in their mother tongue as well as the importance of their understanding of the concepts of science and technology. Nevertheless, this key competency was not included in the fifth and sixth themes; it was covered only once in the seventh theme and twice in the eight theme.

When looking at the key competence of "taking initiative and entrepreneurship", it appears that this competency was included in all preparatory questions unlike all other key competences. The main reason for this is that the questions asked to the students were questions that would contribute to the development of the "activating individual thoughts". Students have to express themselves in an effective way when they take risks, think creatively and innovatively, and answer the questions they are asked. In this respect, students will have taken significant steps to improve these skills by frequently encountering the key competence "taking initiative and entrepreneurship".

The situation in the key competences in the preparatory questions, texts and the activities related to the texts is equally inadequate when the whole book is taken into consideration.

\section{Conclusion}

In the examination, in the preparation phase of the Elementary School Turkish 1 course book, it was seen both in the texts and in the preparatory questions related to the texts and activities that there was no clear systematic way or plan to include the key competences and basic skills in the book. Except for the presence of "mother tongue communication" key competence, other competences and skills were not evenly distributed among the themes. The same holds true for the number of skills. Key competences should be distributed according to a specific plan among the themes, texts, activities and preparatory questions since the basic assertion of all programs is to help students gain competences and skills.

Like the other curriculums renewed in 2017, the Turkish course curriculum aims to develop students' competences and skills in terms of the identified key competences. Turkish course books are expected to develop students' basic skills in terms of key competences like other course books as course books reflect the objectives of their curricula. Turkish course books along with the current course books for all grade levels should be revised and updated in terms of key competences and basic skills, and the newly prepared Turkish course books should be balanced with texts and activities aimed at developing key competences and basic skills. In this respect, each text to be included in books, preparatory questions and activities related to these texts must be meticulously scrutinized so that the key competences and basic skills programs aim to convey to the students should be gained by them. 